\title{
Vegetation structure, floristic composition and species diversity of woody plant communities in sub-tropical Kandi Siwaliks of Jammu, J \& K, India
}

\author{
Neeraj Sharma ${ }^{1}$, Shashi Kant ${ }^{2}$ \\ ${ }^{1}$ Institute of Mountain Environment, Bhaderwah Campus, University of Jammu, Bhaderwah, India \\ ${ }^{2}$ Former Dean Life Sciences \& Head, Department of Botany, University of Jammu, Jammu, India \\ *Corresponding author E-mail: nirazsharma@gmail.com
}

Copyright $\odot 2014$ Neeraj Sharma, Shashi Kant. This is an open access article distributed under the Creative Commons Attribution License, which permits unrestricted use, distribution, and reproduction in any medium, provided the original work is properly cited.

\begin{abstract}
The study was conducted on sub-tropical forest of districts Jammu and Samba of Jammu province of Jammu and Kashmir state, India with the objective of determining floristic composition, species diversity and structure of woody vegetation in drier Kandi Siwaliks. The forests of Kandi belt represent typical subtropical vegetation with distinct vertical zonation of three forest types i.e., Northern dry mixed deciduous forests $(5 \mathrm{~B} / \mathrm{C} 2)$, Himalayan subtropical scrub (9/C1/DSI) and Himalayan subtropical Pine forest (9/C1a) in an altitudinal range of $300 \mathrm{~m}$ asl to $990 \mathrm{~m}$ asl. The community analysis was performed using stratified random sampling involving $0.01 \%$ of the total area for each community. Accordingly, 750 quadrats of $400 \mathrm{~m}^{2}$ and $100 \mathrm{~m}^{2}$ were laid for trees and shrubs respectively after attaining their species area curve. Various phytosociological parameters and diversity indices have been used to reveal the community structure, species richness, diversity and evenness for the phanerophytes in different forest types. A total of 112 species comprising 65 trees and 47 shrubs belonging to 92 genera and 48 families were recorded from the forest. The vegetation analysis revealed the dominance of Mallotus philippensis (SIV \%, 6.4), Acacia modesta (10.44 \%) and Pinus roxburghii (24.27\%) as over storey elements in northern dry mixed deciduous forests, Himalayan subtropical scrub and Himalayan subtropical Pine forest respectively. The northern dry mixed deciduous forests occupying $27.3 \%$ of the study area revealed maximum species richness and diversity as indicated by the higher values obtained for Shannon-Wienner's index and Simpson's index of dominance. Most of the forest landscapes are influenced by human disturbances and thus necessitates the need for immediate conservation action plan to ensure sustainable utilization and better management of forest.
\end{abstract}

Keywords: Community Analysis; Subtropical Vegetation; Phanerophytes; Deciduous Forests; Species Area Curve; Phytosociological Parameters; Human Disturbances.

\section{Introduction}

Forest composition, community structure and diversity patterns are important ecological attributes significantly correlated with prevailing environmental as well as anthropogenic variables [1], [3]. The diversity of tree species is fundamental to total forest biodiversity, because trees provide resources and habitats for almost all other forest species [4], [5]. The tropical and sub-tropical forests harbor maximum diversity of plant species on earth. Covering only $7 \%$ of earth's land surface these forests have more than half of world's species [6]. Of the $86 \%$ of the tropical forests in India, $54 \%$ are classified as dry deciduous and $37 \%$ as moist deciduous [7], [8]. The disappearance of these forests at an estimated rate of 1-2\% per year comes at a time when our knowledge of their structure, composition, dynamics, diversity and taxonomy has not fully unraveled [9]. Kharakwal et al. [10] opines that accelerated species loss could lead to collapse of the ecosystem. Further, these forests are the most disturbed and least protected ecosystems of the world [11] and are disappearing at alarming rates owing to deforestation and unscientific extraction of forest produce [12], [13]. The species diversity, floristic composition and vegetation structure are important to judge the state of natural forests in the region and to suggest conservation strategies thereof. Generally tree species diversity in a forest varies 
greatly from place to place mainly due to variation in biogeography, habitat and disturbance [14]. The local communities residing in and around Kandi belt are dependent upon the forests for an array of ecosystem services and values. The variations in community attributes are directly correlated with the intensity of variable like geographical location, productivity, evolutionary competition and human forest interactions [34]. In Kandi belt, the destruction and fragmentation increases the vulnerability of forest patches especially those at the interfaces thus influencing the composition of vegetation especially the understory significantly. Moreover, the fragile terrain, rocky slopes and geological dips further contribute to varying degrees of natural fragmentation [30], [42].

There have been some important contributions on vegetation analysis, phytosociology and community structure in certain Himalayan forest types [15], [28]. The forest diversity patterns and governing environmental as well as anthropogenic variables in the Himalayan sub-tropical region have been studied in the past by phytosociologists [1], [29], [36]. Similar studies have been carried out in different regions of Jammu province [30], [37], [46]. The present study aims to provide the baseline information on important ecological factors which influence the distribution of vegetation along different ecological and environmental gradients. The ecological attributes, their linkages, stand disturbance regime have been detailed out and viable strategies have been suggested for efficacious management of these vulnerable ecosystems.

\section{Materials and methods}

\subsection{Vegetation sampling and data analysis}

The entire area under study was demarcated using toposheets and satellite imageries and reconnaissance survey was undertaken to define vegetation type and community association. Traverses along roads, drainage, hills and ridges were made and three forest types were identified on the basis of Champion and Seth classification [47]. Physiographic factors i.e., altitude, slope steepness and direction were measured by GPS (Garmin, Rino-130). A total of seven hundred fifty sample points were laid separately for northern dry mixed deciduous (370), Himalayan sub-tropical scrub (280) and Himalayan sub-tropical pine forest (100) respectively for quantitative sampling. Stratified random sampling was adopted for analyzing vegetation composition of woody species. A sample intensity of 0.01 per cent of the total area was adopted covering all vegetation types.

The analysis was carried out by laying the quadrats of $20 \mathrm{~m}^{2}$ each for trees $(\mathrm{gbh}>30 \mathrm{~cm})$ and a nested plot of $10 \mathrm{~m} \times 10$ $\mathrm{m}$ for shrubs/saplings ( $\mathrm{gbh}>17 \mathrm{~cm}$ and $<30 \mathrm{~cm}$ ) in the centre. In case of multi stemmed trees, girth was measured separately. Basal area per hectare was calculated using the formula gi ${ }^{2} / 4 \mathrm{p}$, where gi is the girth of trees at breast height. A single summary statistic or Importance values was calculated by summing the relative values for species according to Ganesh et al. [48]. The equations used is Species Importance Value (SIV\%) $=$ relative frequency + relative density + relative dominance.

\subsection{Species richness and diversity}

Total species richness was simply taken as a count of number of species present in the respective forest type. Species richness (number of species per unit area) was calculated as Margalef's Index [49] using formula Da $=\mathrm{S}-1 / \mathrm{ln}(\mathrm{N})$ and Menhinik's index of richness [50] was calculated as Richness $\mathrm{Db}=\mathrm{S} / \sqrt{ } \mathrm{N}$, where, $\mathrm{S}=$ number of species and $\mathrm{N}=$ Total number of individuals (of all species in case of Menhinik's index). The diversity $\left(\mathrm{H}^{\prime}\right)$ was determined by using Shannon-Weiner information index [51] as $\mathrm{H}^{\prime}=-\sum \mathrm{ni} / \mathrm{n} \log 2 \mathrm{ni} / \mathrm{n}$; where ni was the SIV value of a species and $\mathrm{n}$ was the sum total SIV values of all species in that forest type. Simpson's diversity index [52] was calculated as Ds $=1-\mathrm{Cd}$, Where $\mathrm{Cd}=$ Simpson's concentration of dominance $=\left(\sum \mathrm{ni} / \mathrm{n}\right)^{2}$. Indices used to calculate ' $\mathrm{r}$ ' species evenness included Peilou's Index [53] as $\mathrm{E}_{1}=\mathrm{H}^{\prime} / \mathrm{ln}$ (s) and Sheldon's Index [54] $\mathrm{E}_{2}=\mathrm{eH}^{\prime} / \mathrm{s}$, where $\mathrm{H}^{\prime}$ is Shannon-Wiener's Index and 's' is the number of species. The intensity of disturbance was calculated based on number of cut stumps divided by total number of stems of al tree species including cut stumps in each fragment [19].

\subsection{Study area}

The present study is focused on low-level hill country outside Pir-Panjal and between Jhelum and Ravi constituting Jammu hills, Jammu and Kashmir State, India. The region extends northwards of Pathankote-Jammu national highway covering the southern areas of Kathua, Samba and Jammu districts respectively with an approximate geographical coverage of $3350 \mathrm{sq} \mathrm{km}$ with predominance of typical sub-tropical vegetation ranging from $300 \mathrm{~m}$ asl to $990 \mathrm{~m}$ asl (Fig.-1) The Kandi belt, in local terminology it includes small dry hillocks and gentle slopes made up of boulder mass. Beset with gorges and ravines, the major part of this zone is under forests and offers but limited facility to agriculture. This undulating tract, criss-crossed through a number of shallow seasonal streams locally known as 'Khads' with stony beds, active only during rains. The soils are shallow and infested with gravel and stones. The Jammu Siwaliks has a markedly periodic climate, characterized by dry and increasingly hot season from March to June, a warm humid monsoon season from July to September and a dry and cold weather from October to December. The normal annual 
rainfall of Jammu is $1113 \mathrm{~mm}, 72 \%$ of it is received during monsoon months with average number of rainy days per year being 54. June is recorded as hottest month with average maximum $47^{\circ} \mathrm{C}$ with January being the coldest month with average $6.8^{\circ} \mathrm{C}$. The foggy winters and scorching summers bear a marked climatic perturbation.

\section{Results and discussion}

\subsection{Vegetation structure and composition}

The forests of Kandi Siwaliks were divided into three types in accordance with the classification made in revised survey of forest types of India by Champion and Seth [47].

\subsubsection{Northern dry mixed deciduous forest $(5 \mathrm{~B} / \mathrm{C} 2)$}

Occupying an area of $804.46 \mathrm{~km}^{2}$ accounting to $27.3 \%$ of total geographical area, this forest type is restricted to Jammu foothills of low to moderate elevations (Fig.-1). The area was found richest during monsoon and post-monsoon period with great diversity among epiphytic and herbaceous flora. Among arboreal elements Mallotus philippensis was found gregarious in certain depressions along seasonal streams mainly associated with Cassia fistula especially in the western range. Other associated species included Grewia optiva, Dalbergia sissoo, Toona ciliata, Flacourtia indica, Ficus palmata, Lannea coromandalica, Crataeva adansonii, Mangifera indica, Melia azedarach, Syzigium cumini, Aegle marmelos, Bombax ceiba, Albizia lebbeck, Phyllanthus emblica, Ougenia oogeinensis, Bauhinia variegata, Mitragyna parviflora.

Among shrubs, Dodonaea viscosa formed the conspicuous shrub occurring almost in pure formations and covering large areas of ground in certain places. Isolated thickets of Carissa opaca and patches of Justicia adhatoda were other components interspersed in Dodonaea scrub. Woodfordia fruticosa, Coolebrookia oppositifolia, Capparis sepiaria, Abutilon indicum, Nerium indicum, Punica granatum were seen strikingly abundant and frequently associating. The forest interfaces were heavily infested with dense patches of Lantana camara.

\subsubsection{Himalayan subtropical scrub (9/C1/DSI)}

$296.80 \mathrm{~km}^{2}$, amounting to $10.1 \%$ of the total geographic area under study, recorded the dominance of scrubby vegetation. Restricted to dry hillocks and gentle slopes of low elevation, the fairly dense vegetation cover comprised an admixture of shrubs and rather small sized deciduous trees, mostly of thorny type (Fig.-1). Acacia modesta, which occupied the top and gentle slopes of the hillocks, was the most dominant species, followed by Zizyphus mauritiana and Flacourtia indica. Large patches of Acacia catechu plantations were found along the southern and southeastern slopes. Aegle marmelos, Grewia optiva, Crataeva adansonii, Wrightia tomentosa. Mallotus philippensis, Cassia fistula were only of sporadic occurrence. Bauhinia variegata - Ougenia oogeinensis was the second largest association of this forest. Other usual trees included Lannea coromandelica, Phyllanthus emblica, Premna barbata, Ehretia laevis, Casseria tomentosa, Dalbergia sissoo and Albezia lebbeck.

The dense understory of this forest type comprised of Lantana camara, Carissa opaca, Mimosa rubicaulis, Zizyphus oxyphylla, Randia tetrasperma, Capparis sepiaria and Justicia adhatoda. Lantana camara the most common weed of the area had fully acclimated to the climatic conditions of the region. Dodonaea viscosa, Woodfordia fruticosa, Colebrookia oppositifolia and Punica granatum were found restricted in few patches in association with broadleaved deciduous over storey.

\subsubsection{Himalayan subtropical pine forest $(9 / \mathrm{C} 1 \mathrm{a})$}

This forest type occupied an area of $99.85 \mathrm{~km}^{2}$, thus forming $3.4 \%$ of the total area under study. It comprised of 25-30 m high pure crop of Pinus roxburghii in all the higher ridges and on the steeper rocky slopes at an altitude of 900 $\mathrm{m}$ asl, with broad-leaved species and shrubs towards moderate and lower elevations (Fig.-1). The associations included Acacia catechu, Dalbergia sissoo, Mallotus philippensis, Cassia fistula, Syzigium cumini, Phyllanthus emblica, Ficus palmata, Ficus benghalensis, Lannea coromandelica and Butea monosperma. The undergrowth chiefly comprised of contiguous patches of Dodonaea viscosa and isolated patches of Carissa opaca, Woodfordia fruticosa and Nyctanthes arbro-tristis, Wendlandia heynii, Colebrookia oppositifolia, Justicia adhotoda and Rubus ellipticus. Euphorbia royleana inhabited southern and southwestern rocky slopes. 


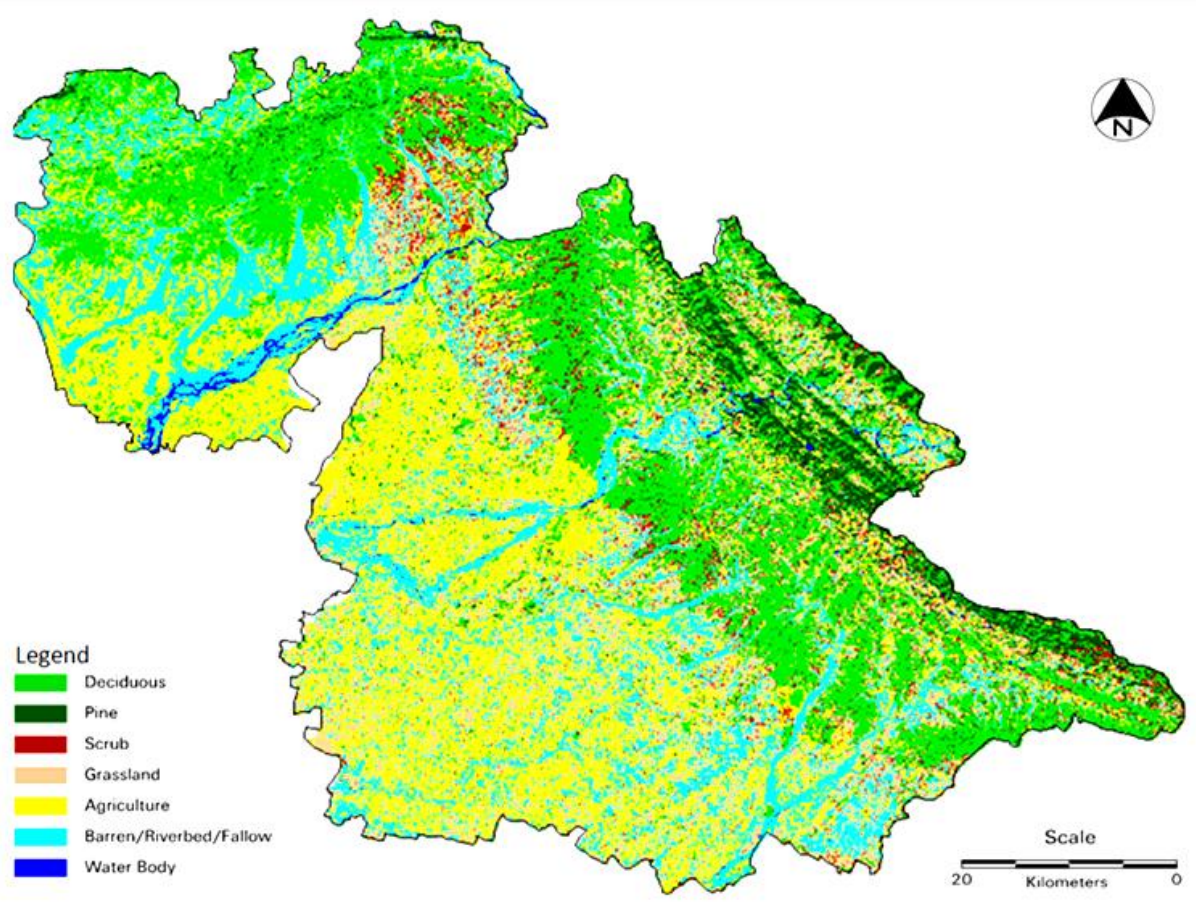

Fig. 1: Land use / Land Cover map of the study area

\subsection{Floristic structure species richness and diversity}

A total of 112 specimens of woody plants (65 Trees and 47 shrubs) in 92 genera and 48 families have been recorded from the study area. These included 4259 individuals from subtropical dry deciduous forest, 4065 in Himalayan subtropical scrub and 1994 in Himalayan subtropical Pine forest. The number of trees per hectare varied from 288, 363 and 498 in subtropical dry deciduous forest, Himalayan subtropical scrub and Himalayan Chirpine dominated forests respectively. Whereas, the under storey exhibited more density than the trees with number of shrubs recorded per hectare arrived to be 376 and 595 in case of subtropical dry deciduous forest and Himalayan subtropical scrub respectively. The least value i.e., 163 shrubs ha $^{-1}$ was recorded in the case of Himalayan subtropical pine forest. The total basal area of trees was found to be $14.32 \mathrm{~m}^{2} /$ ha in subtropical dry deciduous forest, $15.03 \mathrm{~m}^{2} / \mathrm{ha}$ in Himalayan subtropical scrub and $37.75 \mathrm{~m}^{2} /$ ha in Himalayan Chirpine dominated forest.

The canopy trees included the only gymnosperm i.e., Pinus roxburghii besides its broadleaved associates viz., Acacia modesta, Lannea coromandelica, Dalbergia sissoo and Albezia lebbeck, while the middle storey comprised of Cassia fistula, Zizyphus mauritiana, Flacourtia indica, Grewia optiva, Mallotus philippensis. The understory in almost all forest types was dominated by dense patches of cosmopolitan weed Lantana camara followed by Carissa opaca, Justicia adhatoda, Zizyphus oxyphylla, Woodfordia fruticosa, Colebrookia oppositifolia, Capparis sepiaria and Punica granatum.

Among the angiosperm families, Euphorbiaceae topped the list with 9 genera and 9 species followed by Mimosaceae (4/9), Moraceae (2/8), Rubiaceae (5/6) and Verbenaceae (5/6) respectively. As many as 22 families showed monotypic representation in the area as represented by a single genus and single species. Maximum species richness i.e 91 (56 trees and 35 shrubs) was recorded for subtropical dry deciduous forest followed by 68 (44 trees and 24 shrubs) in Himalayan subtropical scrub and 59 (40 trees and 19 shrubs) in Himalayan subtropical pine forest respectively (Table -1). Further, the species diversity was also found maximum in subtropical dry deciduous forest with highest values recorded for Margalef's Index (16.46 for trees / 10.27 for shrubs), Menhinick's Index (1.21 for trees / 0.77 for shrubs), Simpson's Index (0.96 for trees / 0.89 for shrubs) and Shannon-Wiener's Index (3.38 for trees / 2.68 for shrubs) followed by Himalayan subtropical scrub [Margalef's Index (13.19 for trees / 6.86 for shrubs), Menhinick's Index (1.04 for trees / 0.51 for shrubs), Simpson's Index (0.94 for trees / 0.90 for shrubs) and Shannon-Wiener's Index (3.07 for trees / 2.52 for shrubs)] and Himalayan subtropical Pine forest [Margalef's Index (13.47 for trees / 5.84 for shrubs), Menhinick's Index (1.42 for trees / 0.55 for shrubs), Simpson's Index ( 0.82 for trees / 0.88 for shrubs) and Shannon-Wiener's Index (2.48 for trees / 2.52 for shrubs)] respectively (Table -1) 
Table 1: Community Characteristics of Different Forest Ecosystems

\begin{tabular}{|c|c|c|c|c|c|c|}
\hline \multirow{3}{*}{ Parameter } & \multicolumn{6}{|c|}{ Forest Types } \\
\hline & \multicolumn{2}{|c|}{ Subtropical dry deciduous forest } & \multicolumn{2}{|c|}{ Himalayan subtropical scrub } & \multicolumn{2}{|c|}{ Himalayan subtropical Pine forest } \\
\hline & Trees & Shrubs & Trees & Shrubs & Trees & Shrubs \\
\hline Number of families & 30 & 16 & 21 & 17 & 22 & 14 \\
\hline Number of genera & 49 & 29 & 37 & 23 & 38 & 16 \\
\hline Species richness & 56 & 35 & 44 & 24 & 40 & 19 \\
\hline Total number of individuals & 2196 & 2063 & 1826 & 2239 & 784 & 1210 \\
\hline Stand density (individuals ha $^{-1}$ ) & 288 & 376 & 363 & 595 & 498 & 163 \\
\hline Disturbance index $(\%)$ & 5.11 & 2.19 & 7.74 & 1.98 & 4.45 & 2.76 \\
\hline Margalef's Index (Da) & 16.46 & 10.27 & 13.19 & 6.86 & 13.47 & 5.84 \\
\hline Menhinick's Index (Db) & 1.21 & 0.77 & 1.04 & 0.51 & 1.42 & 0.55 \\
\hline Simpson's Index (Ds) & 0.96 & 0.89 & 0.94 & 0.90 & 0.82 & 0.88 \\
\hline Shannon-Wiener's Index $(\mathrm{H})$ & 3.38 & 2.68 & 3.07 & 2.52 & 2.48 & 2.52 \\
\hline Pielou's Index $\left(\mathrm{E}_{1}\right)$ & 0.84 & 0.75 & 0.81 & 0.79 & 0.67 & 0.84 \\
\hline Sheldon's Index $\left(\mathrm{E}_{2}\right)$ & 0.52 & 0.41 & 0.48 & 0.51 & 0.29 & 0.62 \\
\hline
\end{tabular}

The Peilou's evenness Index varied from 0.67 to 0.84 with maximum values recorded as 0.84 for trees and shrubs each in subtropical dry deciduous forest and Himalayan subtropical pine forest respectively. The Sheldon's evenness index ranged from 0.29 to 0.62 with highest value (0.62) noticed in case of shrubs of Himalayan subtropical Pine forest and 0.52 for trees in subtropical dry deciduous Forest. The disturbance index values revealed that Himalayan subtropical scrub with values $7.74 \%$ for trees / $1.98 \%$ for shrubs is moderately disturbed followed by subtropical dry deciduous forest $(5.11 \%$ for trees / $2.19 \%$ for shrubs) and Himalayan subtropical pine forest (4.45\% for trees and $2.76 \%$ for shrubs) (Table -1).

\subsection{Vegetation analysis}

Vegetation analysis shows that highest Species Importance Value (Value, percentage) amongst the trees and shrubs in different forest communities has been recorded for Mallotus philippensis (19.21, 6.4\%) and Carissa opaca (44.15, $14.71 \%)$ in subtropical dry deciduous forest; Acacia modesta $(31.32,10.44 \%)$ and Carissa opaca $(42.48,14.16 \%)$ in Himalayan subtropical scrub, and, Pinus roxburghii $(72.81,24.27 \%)$ and Dodonoea viscosa $(48.61,16.20 \%)$ in Himalayan subtropical pine forest. The other prominent tree species included Dalbergia sissoo (17.76, 5.92\%), Cassia fistula (15.35, 5.11\%), Bombax ceiba (12.07, 4.02\%), Mangifera indica (11.42, 3.80\%), Lannea coromandelica (11.23, $3.74 \%)$ in subtropical dry deciduous forest; Acacia catechu (21.27, 7.09\%), Zizyphus mauritiana (19.07, 6.35\%), Flacourtia indica (16.35, 5.45\%), Dalbergia sissoo (14.34, 4.78\%), Acacia nilotica (12.82, 4.27\%), Butea monosperma $(11.76,3.92 \%)$ in Himalayan subtropical dry scrub. Besides Pinus roxburghii, the other co-dominants in Himalayan Subtropical pine forest included Phoenix sylvistris (15.03, 5.01\%), Mallotus philippensis (13.01, 4.33\%), Lannea coromandelica (12.37, 4.12\%), Ficus benghalensis (12.25, 4.08\%), Bombax cieba (9.93, 3.31\%) etc. The highest density values amongst trees were recorded for Pinus roxburghii (319) in Himalayan subtropical Pine forest followed by Acacia modesta (84.64) in Himalayan subtropical scrub and Mallotus philippensis (48.37) in Subtropical dry deciduous forest. (Table-2.1).

Among the shrubs, the dominant co-associates included Dodonoea viscosa (35.19, 11.73\%), Lantana camara (28.28, $9.42 \%)$, Woodfordia fruticosa $(18.53,6.17 \%)$, Capparis sepiaria $(14.71,4.90 \%)$ in subtropical dry deciduous forest. Lantana camara (35.59, 11.86\%), Dodonoea viscosa (29.06, 9.68\%), Justicia adhatoda (21.35, 7.11\%), Woodfordia fruticosa $(16.60,5.53 \%)$ were the other co-dominants in Himalayan subtropical scrub. The understory of Himalayan subtropical Pine forest, other than the gregarious thickets of Dodonoea viscosa included Carissa opaca (36.86, 12.28\%), Woodfordia fruticosa (28.41, 9.47\%), Colebrookea oppositifolia (23.14, 7.71\%), Justicia adhatoda (19.02, $6.34 \%)$, Zizyphus oxyphylla $(17.39,5.79 \%)$ etc. Among the shrubs, the highest density was found in case of Dodonoea viscosa (294) in Himalayan subtropical Pine forest followed by Carissa opaca (167.50 and 112.16) in Himalayan subtropical scrub and Subtropical dry deciduous forest respectively (Table-2).

\subsection{Discussion}

Our understanding of various aspects of woody species distribution in this part of Himalayas is far from adequate. The edaphic conditions, topography, weather and seasonal pattern coupled with unregulated man-made disturbances have greatly influenced the pattern and distribution of woody species in Kandi Siwaliks. Present study revealed the changing patterns of vegetation composition, diversity and structure in different forest communities. Northern dry mixed deciduous forests occupying $27.3 \%$ of the study area exhibited maximum species richness and diversity. Several factors as less elevation, moist habitat, resource availability, disturbance levels, moderate fragmentation together with stochastic factors like random climatic variability, fluctuations to resources and dispersal limitation may influence the vegetation composition [3], [9], [33], [34], [55] and [56]. The species richness values (40-56 for trees and 19-35 for shrubs) are in accordance to the results of several related phytosociological investigations [31], [34], [57] and [58]. The recorded diversity values $\left(\mathrm{H}^{\prime}\right)$ of 2.48 to 3.38 lie more or less within the reported range of 0.91 to 3.0 for Himalayas 
[59], [61]. Ram et al. [62] reported shrub density between 2.6 to 3.8 for different forest types in Kumaon Himalayas. The values of the present study are in consonance to the values reported for different forest by many workers [10], [17], [28], [58], [63] and [70]. The concentration of dominance (Simpson's index) in the present study sites are within the reported range (0.10- 1) for tropical dry forests by other workers [28], [68], [69], [71] and [72]. The Peilou's evenness Index varied from 0.67 to 0.84 whereas the Sheldon's evenness index ranged from 0.29 to 0.62 . Similar results have been obtained in the studies conducted in other parts of Himalayas [28], [73] and [74].

Table 2.1: Species Importance Value Index of tree species in different forest types of Kandi Siwaliks

\begin{tabular}{|c|c|c|c|c|c|c|c|c|c|c|}
\hline \multirow[b]{2}{*}{ S. No. } & \multirow[b]{2}{*}{ Species } & \multicolumn{3}{|c|}{$\begin{array}{l}\text { Northern dry mixed } \\
\text { deciduous forest }\end{array}$} & \multicolumn{3}{|c|}{$\begin{array}{l}\text { Himalayan subtropical dry } \\
\text { scrub }\end{array}$} & \multicolumn{3}{|c|}{$\begin{array}{l}\text { Himalayan subtropical Pine } \\
\text { forest }\end{array}$} \\
\hline & & $\begin{array}{l}\text { Density } \\
\text { (Trees } \\
\left.\mathrm{Ha}^{-1}\right)\end{array}$ & $\begin{array}{l}\text { Basal } \\
\text { Area } \\
\left(\mathrm{m}^{2}\right) \\
\end{array}$ & SIV (\%) & $\begin{array}{l}\text { Density } \\
(\text { Trees } \\
\left.\mathrm{Ha}^{-1}\right) \\
\end{array}$ & $\begin{array}{l}\text { Basal } \\
\text { Area } \\
\left(\mathrm{m}^{2}\right) \\
\end{array}$ & SIV (\%) & $\begin{array}{l}\text { Density } \\
(\text { Trees } \\
\left.\mathrm{Ha}^{-1}\right) \\
\end{array}$ & $\begin{array}{l}\text { Basal } \\
\text { Area } \\
\left(\mathrm{m}^{2}\right) \\
\end{array}$ & $\operatorname{SIV}(\%)$ \\
\hline 1. & Acacia catechu & 11.35 & 2.19 & 4.83 & 67.50 & 2.86 & 21.37 & 24.00 & 1.83 & 6.87 \\
\hline 2. & Acacia farnesiana & - & - & - & 4.64 & 2.19 & 2.62 & - & - & - \\
\hline 3. & Acacia modesta & 11.89 & 3.90 & 6.29 & 84.64 & 4.47 & 31.32 & 18.00 & 3.36 & 7.45 \\
\hline 4. & Acacia nilotica ssp. Indica & 8.64 & 3.11 & 4.54 & 38.92 & 3.62 & 12.82 & 9.00 & 2.86 & 4.55 \\
\hline 5. & Aegle marmelos & 4.05 & 3.36 & 3.14 & 1.07 & 3.11 & 2.19 & 4.00 & 1.61 & 2.47 \\
\hline 6. & Albizia lebbeck & 10.54 & 4.47 & 5.19 & 13.92 & 4.78 & 7.08 & 5.00 & 3.90 & 4.47 \\
\hline 7. & Bauhinia variegata & 8.64 & 2.86 & 3.74 & 4.64 & 2.77 & 3.14 & 2.00 & 2.63 & 2.64 \\
\hline 8. & Bombax ceiba & 26.21 & 7.18 & 12.07 & 17.50 & 6.52 & 9.28 & 23.00 & 5.19 & 9.93 \\
\hline 9. & Butea monosperma & 10.00 & 2.63 & 4.47 & 34.64 & 3.38 & 11.76 & 2.00 & 2.25 & 2.10 \\
\hline 10. & Casearia tomentosa & 4.59 & 1.61 & 2.21 & 5.00 & 1.85 & 2.46 & 5.00 & 1.61 & 2.59 \\
\hline 11. & Cassia fistula & 40.54 & 3.36 & 15.35 & 23.92 & 2.49 & 9.76 & 15.00 & 3.03 & 5.56 \\
\hline 12. & Cordia dichotoma & 5.67 & 6.62 & 5.25 & 3.57 & 4.18 & 3.38 & 3.00 & 3.11 & 3.11 \\
\hline 13. & Crataeva adansonii & 8.64 & 2.19 & 3.89 & 1.07 & 2.01 & 1.53 & 5.00 & 1.83 & 3.31 \\
\hline 14. & Dalbergia sissoo & 37.83 & 6.81 & 17.76 & 36.42 & 5.48 & 14.34 & 15.00 & 4.47 & 7.85 \\
\hline 15. & Diospyrus cordifolia & 2.43 & 2.63 & 1.98 & - & - & - & - & - & - \\
\hline 16. & Ehretia laevis & 1.08 & 2.19 & 1.49 & - & - & - & - & - & - \\
\hline 17. & Elaeodendron roxburghii & 1.89 & 1.83 & 1.58 & - & - & - & - & - & - \\
\hline 18. & Euphorbia royleana & - & - & - & - & - & - & 25.00 & 3.36 & 8.90 \\
\hline 19. & Ficus cunia & 2.43 & 0.86 & 1.28 & 1.78 & 1.79 & 1.60 & 4.00 & 0.86 & 1.67 \\
\hline 20. & Ficus palmata & 21.35 & 2.93 & 8.56 & 16.78 & 2.19 & 6.66 & 19.00 & 2.63 & 7.92 \\
\hline 21. & Ficus racemosa & 5.13 & 4.04 & 3.46 & 2.14 & 3.62 & 2.65 & 2.00 & 4.04 & 3.66 \\
\hline 22. & Ficus auriculata & 4.59 & 5.19 & 4.12 & 6.07 & 4.18 & 4.30 & 3.00 & 2.19 & 2.47 \\
\hline 23. & Ficus benghalensis & 6.75 & 13.40 & 8.95 & 8.21 & 13.97 & 10.48 & 4.00 & 15.60 & 12.25 \\
\hline 24. & Ficus hispida & 3.51 & 0.98 & 1.71 & 3.92 & 1.61 & 2.16 & - & - & - \\
\hline 25. & Ficus religiosa & 2.97 & 8.36 & 5.24 & 3.21 & 6.81 & 5.08 & - & - & - \\
\hline 26. & Flacourtia indica & 23.24 & 3.76 & 9.25 & 41.78 & 3.98 & 16.35 & 24.00 & 3.76 & 7.65 \\
\hline 27. & Flueggea virosa & 6.21 & 2.25 & 3.32 & - & - & - & - & - & - \\
\hline 28. & Gmelina arborea & 4.59 & 3.65 & 3.18 & 1.07 & 2.47 & 1.80 & - & - & - \\
\hline 29. & Grewia optiva & 22.43 & 3.49 & 8.59 & 12.14 & 3.26 & 4.94 & 19.00 & 2.93 & 7.56 \\
\hline 30. & Helicteres isora & 2.43 & 0.98 & 1.40 & - & - & - & - & - & - \\
\hline 31. & Hiptage benghalensis & 1.62 & 1.74 & 1.37 & - & - & - & - & - & - \\
\hline 32. & Holarrhena antidysenterica & 1.35 & 0.88 & 0.91 & - & - & - & - & - & - \\
\hline 33. & Lannea coromandelica & 24.86 & 4.47 & 11.23 & 31.78 & 6.44 & 13.24 & 31.00 & 5.19 & 12.37 \\
\hline 34. & Leea edgeworthii & 3.24 & 0.69 & 1.34 & - & - & - & - & - & - \\
\hline 35. & Mallotus philippensis & 48.37 & 3.03 & 19.21 & 21.42 & 2.49 & 8.16 & 39.00 & 3.03 & 13.01 \\
\hline 36. & Mangifera indica & 21.35 & 8.94 & 11.42 & 20.00 & 7.37 & 11.04 & 4.00 & 6.81 & 6.39 \\
\hline 37. & Melia azedarach & 9.72 & 3.70 & 5.42 & 5.71 & 2.79 & 3.32 & 7.00 & 2.70 & 3.33 \\
\hline 38. & Moringa oleifera & 5.94 & 2.70 & 3.15 & 4.64 & 1.59 & 2.09 & - & - & - \\
\hline 39. & Morus alba & 2.16 & 3.16 & 2.20 & - & - & - & - & - & - \\
\hline 40. & Oroxylum indicum & 6.75 & 2.03 & 2.97 & 1.78 & 1.66 & 1.52 & 3.00 & 0.98 & 1.62 \\
\hline 41. & Ougeinia oogeinensis & 4.86 & 2.60 & 2.72 & 2.85 & 1.16 & 1.55 & 4.00 & 1.83 & 2.34 \\
\hline 42. & Phanera vahlii & - & - & - & - & - & - & 15.00 & 1.61 & 5.85 \\
\hline 43. & Phoenix sylvestris & 1.62 & 5.09 & 2.90 & 3.92 & 3.98 & 3.58 & 43.00 & 5.19 & 15.03 \\
\hline 44. & Phyllanthes emblica & 10.27 & 2.91 & 4.79 & 6.78 & 3.41 & 4.20 & 3.00 & 2.30 & 2.54 \\
\hline 45. & Pinus roxburghii & 38.01 & 7.18 & 14.07 & 20.71 & 5.19 & 9.57 & 319.00 & 7.18 & 72.81 \\
\hline 46. & Pistacea integeriima & 6.21 & 5.19 & 4.73 & 3.92 & 5.21 & 3.55 & 3.00 & 3.90 & 3.94 \\
\hline 47. & Premna latifolia & 3.51 & 2.47 & 2.23 & - & - & - & - & - & - \\
\hline 48. & Pyrus pashia & 6.21 & 2.74 & 3.56 & 2.14 & 2.25 & 1.92 & 9.00 & 2.75 & 4.18 \\
\hline 49. & Sapium sebiferum & 2.43 & 1.83 & 1.60 & - & - & - & - & - & - \\
\hline 50. & Syzygium cumini & 17.02 & 6.92 & 8.79 & 9.64 & 5.57 & 6.12 & 15.00 & 4.47 & 7.57 \\
\hline 51. & Terminalia bellirica & 11.08 & 9.02 & 7.64 & 2.85 & 7.76 & 5.50 & 1.00 & 9.02 & 6.70 \\
\hline 52. & Terminalia chebula & 8.37 & 6.82 & 5.20 & - & - & - & - & - & - \\
\hline 53. & Toona ciliata & 10.54 & 5.82 & 6.36 & 7.50 & 5.03 & 5.29 & - & - & - \\
\hline 54. & Trema politoria & 2.43 & 1.83 & 1.47 & - & - & - & - & - & - \\
\hline 55. & Wendlandia heynei & 23.51 & 2.30 & 7.94 & 12.85 & 2.36 & 5.73 & 29.00 & 1.83 & 9.19 \\
\hline 56. & Wrightia tomentosa & 3.78 & 2.84 & 2.58 & 1.78 & 1.48 & 1.41 & 1.00 & 1.68 & 1.57 \\
\hline 57. & Xylosma longifolium & 0.81 & 1.68 & 1.06 & 5.35 & 1.14 & 2.28 & 3.00 & 2.19 & 2.75 \\
\hline 58. & Zanthoxylum alatum & 0.54 & 1.47 & 0.92 & 2.14 & 1.89 & 1.79 & 2.00 & 2.19 & 2.34 \\
\hline 59. & Zizyphus mauritiana & 19.72 & 5.19 & 9.36 & 49.64 & 6.20 & 19.07 & 23.00 & 5.09 & 9.86 \\
\hline
\end{tabular}


Table 2.2: Species Importance Value Index of shrub / sapling species in different forest types of Kandi Siwaliks

\begin{tabular}{|c|c|c|c|c|c|c|c|c|c|c|}
\hline \multirow[b]{2}{*}{$\begin{array}{l}\text { S. } \\
\text { No. }\end{array}$} & \multirow[b]{2}{*}{ Species } & \multicolumn{3}{|c|}{ Northern dry mixed deciduous forest } & \multicolumn{3}{|c|}{ Himalayan subtropical dry scrub } & \multicolumn{3}{|c|}{ Himalayan subtropical Pine forest } \\
\hline & & $\begin{array}{l}\text { Density } \\
(\text { Shrubs / } 100 \\
\left.\mathrm{m}^{2}\right)\end{array}$ & $\begin{array}{l}\text { Basal } \\
\text { Area } \\
\left(\mathrm{m}^{2}\right) \\
\end{array}$ & $\begin{array}{l}\text { SIV } \\
(\%)\end{array}$ & $\begin{array}{l}\text { Density } \\
(\text { Shrubs / } 100 \\
\left.\mathrm{m}^{2}\right)\end{array}$ & $\begin{array}{l}\text { Basal } \\
\text { Area } \\
\left(\mathrm{m}^{2}\right) \\
\end{array}$ & $\begin{array}{l}\text { SIV } \\
(\%)\end{array}$ & $\begin{array}{l}\text { Density } \\
(\text { Shrubs / } 100 \\
\left.\mathrm{m}^{2}\right)\end{array}$ & $\begin{array}{l}\text { Basal } \\
\text { Area } \\
\left(\mathrm{m}^{2}\right)\end{array}$ & $\begin{array}{l}\text { SIV } \\
(\%)\end{array}$ \\
\hline 1. & Abutilon indicum & 9.45 & 0.41 & 7.46 & 26.07 & 0.265 & 10.90 & - & - & - \\
\hline 2. & Abutilon ramosum & 2.97 & 0.23 & 3.19 & 4.64 & 0.191 & 2.68 & - & - & - \\
\hline 3. & Agave sisalana & 2.16 & 0.56 & 6.13 & 10.35 & 0.591 & 7.68 & - & - & - \\
\hline 4. & Antidesma diandrum & 2.70 & 0.63 & 7.09 & - & - & - & - & - & - \\
\hline 5. & $\begin{array}{l}\text { Asparagus } \\
\text { adscendens }\end{array}$ & 4.59 & 0.18 & 3.41 & 15.35 & 0.137 & 6.02 & 28.00 & 0.23 & 8.41 \\
\hline 6. & Buddleja asiatica & 19.72 & 0.42 & 10.27 & 12.85 & 0.430 & 7.76 & 49.00 & 0.42 & 13.08 \\
\hline 7. & Calotropis procera & 11.08 & 0.06 & 5.54 & 28.92 & 0.134 & 8.77 & - & - & - \\
\hline 8. & Capparis sepiaria & 35.40 & 0.23 & 14.71 & 45.00 & 0.257 & 15.64 & 29.00 & 0.18 & 6.52 \\
\hline 9. & Carissa opaca & 112.16 & 0.58 & 44.15 & 167.50 & 0.704 & 42.48 & 179.00 & 0.58 & 36.86 \\
\hline 10 & $\begin{array}{l}\text { Colebrookea } \\
\text { oppositifolia }\end{array}$ & 19.18 & 0.25 & 9.76 & 31.78 & 0.477 & 14.13 & 93.00 & 0.48 & 23.14 \\
\hline 11. & $\begin{array}{l}\text { Deeringia } \\
\text { amaranthoides }\end{array}$ & 4.05 & 0.13 & 2.43 & - & - & - & - & - & - \\
\hline 12. & Dodonoea viscosa & 92.70 & 0.48 & 35.19 & 101.07 & 0.474 & 29.06 & 294.00 & 0.60 & 48.61 \\
\hline 13. & Euphorbia royleana & 6.21 & 0.76 & 9.32 & 12.50 & 0.669 & 10.11 & 34.00 & 0.76 & 14.70 \\
\hline 14. & Glochidion velutinum & 1.35 & 0.13 & 1.75 & - & - & - & - & - & - \\
\hline 15. & $\begin{array}{l}\text { Gymnosporia } \\
\text { royleana }\end{array}$ & 2.16 & 0.23 & 2.83 & 4.64 & 0.257 & 4.03 & - & - & - \\
\hline 16. & Indigofera cassioides & 1.35 & 0.13 & 1.28 & - & - & - & - & - & - \\
\hline 17. & Indigofera tinctoria & 1.89 & 0.09 & 1.84 & - & - & - & - & - & - \\
\hline 18. & Ipomea caricia & - & - & - & 17.50 & 0.092 & 5.16 & - & - & - \\
\hline 19. & $\begin{array}{l}\text { Jasminum } \\
\text { auriculatum }\end{array}$ & 0.54 & 0.26 & 2.73 & - & - & - & - & - & - \\
\hline 20. & Justicia adhatoda & 37.56 & 0.19 & 13.75 & 78.21 & 0.236 & 21.35 & 93.00 & 0.21 & 19.02 \\
\hline 21. & $\begin{array}{l}\text { Lantana camara var. } \\
\text { aculeate }\end{array}$ & 79.72 & 0.39 & 28.28 & 114.64 & 0.527 & 35.59 & 53.00 & 0.26 & 12.53 \\
\hline 22. & Mimosa rubicaulis & 8.91 & 0.23 & 5.69 & 20.00 & 0.449 & 8.65 & 37.00 & 0.51 & 13.73 \\
\hline 23. & Murraya koenigii & 26.75 & 0.23 & 9.18 & - & - & - & - & - & - \\
\hline 24. & Myrsine africana & 0.54 & 0.09 & 1.14 & - & - & - & - & - & - \\
\hline 25. & Neruim indicum & - & - & - & 11.42 & 0.302 & 5.90 & - & - & - \\
\hline 26. & $\begin{array}{l}\text { Nyctanthes } \\
\text { arbortristis }\end{array}$ & 8.37 & 0.13 & 3.59 & - & - & - & 11.00 & 0.16 & 4.28 \\
\hline 27. & $\begin{array}{l}\text { Pogostemon } \\
\text { benghalense }\end{array}$ & 1.08 & 0.07 & 1.14 & - & - & - & - & - & - \\
\hline 28. & Punica granatum & 7.83 & 0.51 & 7.27 & 10.35 & 0.635 & 9.01 & 29.00 & 0.48 & 10.53 \\
\hline 29. & Randia tetrasperma & 10.00 & 0.76 & 10.19 & 10.71 & 0.646 & 8.96 & 9.00 & 0.62 & 9.51 \\
\hline 30. & Rhamnus triquetra & 0.81 & 0.19 & 2.11 & - & - & - & 5.00 & 0.21 & 3.59 \\
\hline 31. & Rubus ellipticus & 17.56 & 0.23 & 8.13 & 8.21 & 0.580 & 7.40 & 63.00 & 0.23 & 13.79 \\
\hline 32. & $\begin{array}{l}\text { Spermadictyon } \\
\text { suaveolens }\end{array}$ & 4.59 & 0.31 & 4.20 & 3.92 & 0.161 & 2.39 & 5.00 & 0.31 & 5.04 \\
\hline 33. & Vitex negundo & 6.21 & 0.63 & 7.69 & 7.509 & 0.580 & 7.41 & 19.00 & 0.56 & 10.57 \\
\hline 34. & Vitis latifolia & 2.43 & 0.14 & 2.47 & - & - & - & - & - & - \\
\hline 35. & Woodfordia fruticosa & 32.70 & 0.37 & 18.53 & 31.78 & 0.704 & 16.60 & 109.00 & 0.58 & 28.41 \\
\hline 36. & Zizyphus oxyphylla & 4.59 & 0.23 & 4.31 & 24.64 & 0.548 & 12.58 & 71.00 & 0.42 & 17.39 \\
\hline
\end{tabular}

Fragmentation of natural forest due to anthropogenic pressure is a common phenomenon. Disproportionate growth in human and livestock population over the last few decades in this region is posing significant threat to these ecosystems. The present study confirms moderate degree of disturbance in Himalayan subtropical scrub followed by Himalayan Chirpine and subtropical dry deciduous forest. Similar results have been obtained during the studies in similar ecosystems [33], [42] and [73]. The distribution of Chirpine is very narrow and the patches are more or less exposed to southern which being dry expose these stands to intense and frequent forest fires which is in conformity to other similar investigations [30], [42] and [75].

The tree density recorded as 288, 363 and 498 per hectare in subtropical dry deciduous forest, Himalayan subtropical scrub and Himalayan Chirpine dominated forest respectively is comparatively less than the recorded standards for subtropical forests in other Himalayan regions like $534-620 \mathrm{Ha}^{-1}$ in lesser Himalayas [76]; $1158 \mathrm{Ha}^{-1}$ in Himachal Pradesh [77], [78]; 530-940 Ha ${ }^{-1}$ in Kumaon Himalayas [31], [79]; 790-1059 $\mathrm{Ha}^{-1}$ in Gharwal Himalayas [32], [80] and 341$462 \mathrm{Ha}^{-1}$ in Nepal broadleaved forests [81] and $344 \mathrm{Ha}^{-1}$ in Bagh district of Kashmir, Pakistan [34]. The under storey, however exhibits more density and abundance near the forest interfaces thus reflecting pronounced edge effect.

\section{Conclusions}

Forest destruction and fragmentation often leads to reduction of species richness, diversity and significantly affect ecosystem health and resilience. The forests in Kandi Siwaliks over the years have witnessed reduction of forested areas, isolation of smaller patches, habitat loss and rise in disturbance level. Large fragments which were less disturbed, subtropical dry deciduous forest in this case harboured more species and healthy over and understory as compared to 
subtropical scrub and Chirpine forest. Therefore to conserve plant diversity around the forest-village/town interfaces a protective buffer of edge species around newly created fragmented forest patches is required to protect the core species.

\section{Acknowledgements}

The financial assistance was gratefully received in Department of Space \& Department of Biotechnology (Govt. of India) sponsored project on 'Biodiversity characterization at landscape level in western Himalayas using remote sensing and Geographical Information System.

\section{References}

[1] Gairola, S., R.S. Rawal and N.P Todaria, "Forest vegetation patterns along an altitudinal gradient in sub-alpine zone of west Himalaya, India," African Journal of Plant Science, 2, 6, (2008), 42-48.

[2] Timilsina, N., M.S. Ross and J.T. Heinen., "A community analysis of Sal (Shorea robusta) forests in the western Terai of Nepal", Forest Ecology and Management, 241, (2007), 223-234. http://dx.doi.org/10.1016/j.foreco.2007.01.012.

[3] Ahmad I, M.S.A Ahmad, M. Hussain, M. Ashraf, M.Y. Ashraf \& M. Hameed, "Spatiotemporal aspects of plant community structure in open scrub rangelands of sub mountainous Himalayan plateaus", Pakistan J. Bot. 42, 5, (2010),3431- 3440.

[4] Hall, J.B. and M.D Swaine, "Classification and ecology of closed-canopy forest in Ghana", Journal of Ecology 64 (1976), 913-951. http://dx.doi.org/10.2307/2258816.

[5] Huang, W, V. Pohjonen, S. Johanson, M.I.L. Katigula \& O. Lukkanen, "Species diversity, Forest structure and species composition in Tanzanina tropical forests", Forest Ecology and Management, 173 (2003), 11-24 http://dx.doi.org/10.1016/S0378-1127 (01)00820-9.

[6] May, R.M. \& M.P.H. Stumpf, "Species-area relations in tropical forests", Science, 290, (2000), $2084-2086$. http://dx.doi.org/10.1126/science.290.5499.2084

[7] Kaul, O.N. \& D.C. Sharma. "Forest type Statistics", Indian Forester, 97, (1971), 432-436.

[8] Singh, K.P. \& C.P. Kushwaha, "Emerging paradigms of tree phenology in dry tropics", Current Science 89, (2005), 964-975.

[9] Hubbell, S.P., R.B. Foster, S.T. O'brien, K.E. Harms, R. Condit, B. Wechsler, S.J. Wright and S. Loo De Lao, "Light-gap disturbances, recruitment limitation, and tree diversity in a neotropical forests", Science, 283, (1999), 554-557. http://dx.doi.org/10.1126/science.283.5401.554.

[10] Kharkwal, G., P. Mehrotra \& Y.S. Pangtey, "Comparative studies on species richness, diversity and composition of oak forests in Nainita district, Uttaranchal", Current Science 89, (2005), 668-672.

[11] Murphy, P.G. \& A.E. Lugo, "Structure and biomass of subtropical dry forest in Puerto Rico", Biotropica 18, (1986), 89-96 http://dx.doi.org/10.2307/2388750.

[12] Hare M.A, D.O. Lantagne, P.G. Murphy \& H. Chero, "Structure and tree species composition in a subtropical dry forest in the Dominican Republic: comparison with a dry forest in Puerto Rico", Tropical Ecology, 38, 1, (1997), 1-17.

[13] Raghubanshi A.S \& A. Tripathi, "Effect of disturbance, habitat fragmentation, and alien invasive plants on floral diversity in dry tropical forests of Vindhyan Highlands: a review", Tropical Ecology 50, 1, (2009), 57-69.

[14] Whitmore, T.C, An introduction to tropical rain forests. Oxford University Press, New York, 1998.

[15] Ralhan P.K., A.K. Saxena \& J.S. Singh, "Analysis of forest vegetation at and around Nainital in Kumaon Himalayas", Proc. Indian Nat. Sci. Acad., 48, 1, (1982), 121-137

[16] Saxena A.K. \& J.S. Singh, A phytosociological analysis of woody plant species in forest communities of a part of Kumaon Himalaya, Vegetatio 50, (1982), 3-22. http://dx.doi.org/10.1007/BF00120674.

[17] Singh, S.P \& J.S Singh, "Structure and function of the central Himalayan Oak forests. Proceedings Indian Academy of Science", Plant Science 96, (1986), 159-189.

[18] Singh R.S, P.K. Ralhan \& S.P. Singh, "Phytosociology and population structure of Oak mixed conifer forest in a part of Kumaon Himalayas", Environment and Ecology, 5, (1987), 475-487.

[19] Rao P, S.K. Barik, H.N. Pandey \& R.S. Tripathi, "Community composition and tree population structure in sub-tropical broadleaved forest along a disturbance gradient" Vegetatio, 88 (1990), 151-162. http://dx.doi.org/10.1007/BF00044832.

[20] Sharma C.M. \& A. Kumar, "Community structure of some natural forest stands in Lansdowne Forest range of Garhwal Himalayas", J. Trop. For. Sci., 5, (1992), 8-12.

[21] Varghese A.O. \& A.R.R. Menon, "Vegetation characteristics of southern secondary moist mixed deciduous forests of Agasthyamalai region of Kerala", Indian Journal of Forester 21,4, (1998), 337-344.

[22] Pande P.K., J.D.S. Negi, C. Sharma, "Plant species diversity, composition, gradient analysis and regeneration behavior of some tree species in a moist temperate Western Himalayan Forest ecosystem", Indian Forester, 8, (2002), 869-886.

[23] Ilorkar V.M. \& P.K. Khatri, "Phytosociological study of Navegaon national Park, Maharashtra", Ind. For. 129, 3, (2003), $377-387$.

[24] Negi SC \& S Nautyial, "Phytosociological studies of a traditional reserve forests Thal-ke-Dhar, Pithoragarh, Central Himalayas, India", Indian Forester, 131, 4, (2005), 519-532.

[25] Naithani H.B., R.C. Pal \& R.K. Srivastava, "Vegetation analysis of the Trimula hills, Andhra Pradesh", Indian Forester, 132, 9, (2006),11101130 .

[26] Sanjeev M, P.L .Gera \& Sankhyan, "Phytosocilogical analysis of Arnigad micro-watershed in Mussoorie hills of Garhwal Himalayas", Indian Forester, 132, 1, (2006), 19-30.

[27] Sahu S.C, N.K. Dhal, C.S. Reddy, C. Pattanaik \& M. Brahmam, "Phytosociological study of tropical dry deciduous forest of Boudh district, Orissa, India", Research Journal of Forestry, 1, (2007), 66-72. http://dx.doi.org/10.3923/rjf.2007.66.72.

[28] Tynsong H. \& B.K. Tiwari, "Diversity and population characteristics of woody species in natural forests and arecanut agroforests of south Meghalaya, Northeast India", Tropical Ecology 52, 3, (2011), 243-252

[29] Kunwar, R.M. \& S.P. Sharma, "Quantitative analysis of tree species in two community forests of Dolpa district, mid-west Nepal", Him J Sci., $2,3,(2004), 23-28$.

[30] Sharma N, "Biodiversity characterization at landscape level in Jammu district of J \& K (Western Himalayas) using remote sensing and GIS", Ph.D Thesis, University of Jammu, (J \& K), India, 2003.

[31] Kharkwal, G, "Qualitative analysis of tree species in evergreen forests of Kumaon Himalaya, Uttarakhand, India", African Journal of Plant Science, 3, 3, (2009), 49-52

[32] Todaria, N.P., Prerna Pokhriyal, Pooja Uniyal \& D.S. Chauhan, "Regeneration status of tree species in forest of Phakot and Pathri Rao watersheds in Garhwal Himalaya", Current Science, 98, 2, (2010), 171-175. 
[33] Tripathi, O.P., K. Upadhaya, R.S. Tripathi \& H.N. Pandey, "Diversity, dominance and population structure of tree species along fragmentsize gradient of a sub-tropical humid forest of northeast India", Research journal of Environmental and Earth sciences 2, 2, (2010), 97-105.

[34] Shaheen, H., R.A. Qureshi \& Z.A. Shinwari, "Structural diversity, vegetation dynamics and anthropogenic impact on lesser Himalayan subtropical forests of Bagh district, Kashmir", Pak.J.Bota., 43,4, (2011), 1861-1866.

[35] Tiwari, G.B.G. Pananjay \& S.C. Tiwari, "Species diversity and environmental Regeneration potential of tree species along an altitudinal gradient in subtropical montane forests of a central Himalaya, India", International Journal of basic and Applied sciences 1, 1, (2012), $27-37$.

[36] Bargali, K., P. Bisht, A. Khan, \& Y.S. Rawat, "Diversity and regeneration status of tree species at Nainital catchment, Uttarkhand, India", International Journal of Biodiversity and conservation, 5, 5, (2013), 270-280.

[37] Kumar A, "Phytosociological and productivity studies of Bhaderwah forests, Jammu (J \& K)", Ph.D Thesis, University of Jammu, Jammu (J\&K), India, 1987.

[38] Kumar K., "Studies on plant diversity of Patnitop and adjoining area and impact of biotic activities", Ph.D Thesis, University of Jammu, Jammu (J \& K), India, 1997.

[39] Kour, I., "Phytodiversity and impact of tourism on the vegetation of Trikuta Hills (J\&K)", Ph.D. Thesis, University of Jammu, Jammu, (J\&K), India, 2001.

[40] Singh J, "Phytodiversity of Kalakote range (Rajouri, J\&K) and impact of mining and nomadism on the vegetation", Ph.D thesis, University of Jammu, Jammu (J\&K), India. 2002

[41] Kesar, R.K., "Phytosociological and community studies of Patnitop forests and their management", Ph.D. Thesis. University of Jammu, Jammu, (J\&K), India, 2002.

[42] Jhangir M, "Phytodiversity characterisation using remote sensing and GIS of district Kathua, Jammu and Kashmir", Ph.D thesis, University of Jammu (J\&K), Jammu, India, 2004.

[43] Dutt H, "Ecological studies and conservation of medicinal plants of Neeru watershed J \& K", Ph.D thesis, University of Jammu, Jammu (J \& K), India, 2005.

[44] Kumar V., "Studies on plant diversity of spermatophytes of Parnai watershed, Poonch", Ph.D thesis, University of Jammu, Jammu (J \&K), India, 2007.

[45] Raina, A \& N. Sharma, "Species composition and diversity of tree species along an altitudinal gradient in Sewa catchment of north-western Himalayas, Jammu and Kashmir, India", Env. Cons. J, 13, 1 \& 2, (2012), 173-179.

[46] Sharma N., and A. Raina, "Composition, structure and diversity of tree species along an altitudinal gradient in Jammu province of northwestern Himalayas, Jammu and Kashmir, India", Journal of Biodiversity and Environmental Sciences 3, 10, (2013), 12-23.

[47] Champion H.G \& S.K. Seth, "A revised survey of the forest types of India", Manager of publication, Govt. of India, New Delhi, India, 404, (1968).

[48] Ganesh,T.R, M. Ganesan, S. Devy, P. Davidar \& K.Bawa, "Assessment of plant biodiversity at a mid-elevation evergreen forest of KalakadMandanthurai Tiger Reserve, Western Ghats, India", Current Science, 71, (1996), 379-392.

[49] Margalef D.R, "Information theory in ecology", Genetics and systematic, 3, (1958), 36-71.

[50] Whittaker R.H, "Evolution of species diversity in land plant communities", Evolutionary biology, 10, (1977), 1-67.

[51] Shanon C.E \& W. Weaver, The mathematical theory of communication, University of Illinois Press, Urbana, USA, 1963

[52] Simpson E.H, "Measurement of diversity", Nature, (1949), 163-168

[53] Pielou, E.C, Ecological diversity, John Wiley and Sons, New York, 1975.

[54] Sheldon. A. L, "Equitability indices: Dependence on the species count", Ecology, 50, (1969), 466-467. http://dx.doi.org/10.2307/1933900.

[55] Connell, J.H, "Some processes affecting the species composition in forest gaps", Ecology, 70, (1989), 560-562. http://dx.doi.org/10.2307/1940205.

[56] Dalling, J.W., H.C. Muller-Landau, S.J. Wright and S.P. Hubbell, "Role of dispersal in the recruitment limitation of neo-tropical pioneer species", J. Ecol., 90, (2002), 714-727. http://dx.doi.org/10.1046/j.1365-2745.2002.00706.x.

[57] Behera M.D \& P.S. Roy, "Assessment of biological richness in different altitudinal zones in eastern Himalayas Arunachal Pradesh, India", Current Science, 88, 2, (2005), 25.

[58] Krishnamurthy Y.L., H.M. Prakasha, A. Nanda, M. Krishnappa, H.S. Dattaraja \& H.S. Suresh, "Vegetation structure and floristic composition of a tropical dry deciduous forest in Bhadra Wildlife Sanctuary, Karnataka, India", Tropical Ecology, 51, 2, (2010), 235-246.

[59] Pande, P.K, "Quantitative vegetation analysis as per aspect and altitude, and regeneration behaviour of tree species in Garhwal Himalayan forest", A For., 9, 1, (2001), 39-52.

[60] Mishra, C., H.T. Prins \& Van Wieren, "Diversity, Risk Mediation, and Change in a Trans-Himalayan Agropastoral System", Human Ecology, 31, 4, (2003), 595-609.

[61] Sharma D., Pham V. Hoa, T.V. Cuong, T. Tuyen \& N. Sharma. Forest fire risk zonation for Jammu district forest division using Remote Sensing and GIS. Proc. 7th FIG regional conference: Spatial data serving people land governance and the environment, Hanoi, Veitnam (2009), 1-12.

[62] Ram J, A. Kumar \&, J. Bhatt, "Plant diversity in six forest types of Uttarakhand Central Himalayas, India", Current Science, 87, 7, (2004), 975-978.

[63] Singh J.S., S.P. Singh, A.K. Saxena \& Y.S. Rawat, "The forest vegetation of Silent Valley in India", In: Tropical Rain Forest: The Leeds Symposium (eds. Chadwick AC and Sutton SL), Leeds Philosophical and Literary Society, Leeds, U.K, (1985), 25-52.

[64] Pande, P.K., J.D.S Negi, \& S.C Sharma, "Plant species diversity, composition, gradient analysis and regeneration behavior of some tree species in a moist temperate western Himalayan forest ecosystem", Indian Forester, 128, 8, (2002), 869-889.

[65] Rasingam L., \& N. Parthasarthy, "Tree species diversity and population structure across major forest formations and disturbance categories in Little Andaman Island, India", Tropical Ecology 50, 1, (2009), 89-102.

[66] Shukla R.P, "Patterns of plant diversity across Terai landscape in north-eastern Uttar Pradesh, India", Tropical Ecology 50, 1, (2009), $111-123$.

[67] Tripathi K.P. \& B. Singh, "Species diversity and vegetation structure across various strata in natural and plantation forests in Katerniaghat Wildlife Sanctuary, North India", Tropical Ecology 50, 1, (2009), 191-200.

[68] Joshi H.G, "Vegetation structure, floristic composition and soil nutrient status in three sites of tropical dry deciduous forest of West Bengal, India", Indian Journal of Fundamental and Applied Life Sciences, 2, 2, (2012), 355-364.

[69] Sahu S.C, N.K. Dhal, R.C Mohanty, "Tree species diversity, distribution and population structure in tropical dry deciduous forest of Malygiri hill ranges, Eastern India", Tropical Ecology, 53, 2, (2012), 163-168

[70] Gunaga, S., N. Rajeshwari \& R Vasudeva, "Tree diversity and disturbance of Kaan forests: relics of a community protected climax vegetation in the central Western Ghats", Tropical Ecology 54, 1, 2013, 117-131.

[71] Visalakshi N, "Vegetation analysis of two tropical dry evergreen forests in southern India", Tropical Ecology 36, 1, (1995), 117-127.

[72] Kumar J.I.N, R.N. Kumar, R.K. Bhoi \& P.R. Sajish, "Tree species diversity and soil nutrient status in three sites of tropical dry deciduous forest of western India", Tropical Ecology 51, 2, (2010), 273-279.

[73] Behera, M.D, S.P.S. Kushwara, P.S. Roy, S. Srivastava, T.P. Singh \& R.C. Dubey, "Comparing structure and composition of coniferous forests in Subansiri district, Arunachal Pradesh", Current Science, 82, 1, (2002), 70-75.

[74] Feroz, S.M., K.Yoshimura \& A. Hagihara, "Architectural stratification and woody species diversity of a subtropical forest frown in a limestone habitat in Okinawa island, Japan", World academy of Science, Engineering and Technology, 2, (2008), 11-20. 
[75] Sharma, C.M., S.K. Ghildiyal, S. Gairola and S. Suyal, "Vegetation structure, composition and diversity in relation to the soil characteristics of temperate mixed broad-leaved forest along an altitudinal gradient in Garhwal Himalaya", Ind. J. Sci. Technol., 2, 7, (2009), 39-45

[76] Ahmed, M., T. Husain, A.H.S. Heikh, S.S. Hussain and M Siddiqui, "Phytosociology and structure of Himalayan forests from different climatic zones of Pakistan", Pak. J. Bot., 8, 2, (2006), 361-383

[77] Sharma, R.K., P.L. Sankhayan and Ole Hofstad, "Forest biomass density, utilization and production dynamics in a western Himalayan watershed", Journal of Forestry Research, 19 3, (2008), 171-180.

[78] Sundriyal, R.C., E. Sharma, L.K. Rai and S.C. Rai, "Tree structure, regeneration and woody biomass removal in a sub-tropical forest of Mamlay watershed in the Sikkim Himalaya", Vegetatio, 11,3, (1994), 53-63.

[79] Hussain, M.S., A. Sultana, J.A. Khan and A. Khan, "Species composition and community structure of forest stands in Kumaon Himalaya, Uttarakhand, India", Tropical Ecology, 49,2, (2008), 167-181.

[80] Kusumlata and N.S. Bisht, "Quantitative analysis and regeneration potential of moist temperate forest in Garhwal Himalaya", Indian Journal of Forestry, 14, 2, (1991), 98-106.

[81] Subedi, M.N. and P.R. Shakya, "Above ground biomass and productivity studies of Quercus semecarpifolia forest in Nepal", presented in CHEA, INTACH workshop on Biomass, production and utilization strategies, Nainital, India. (1988), 381-385. 